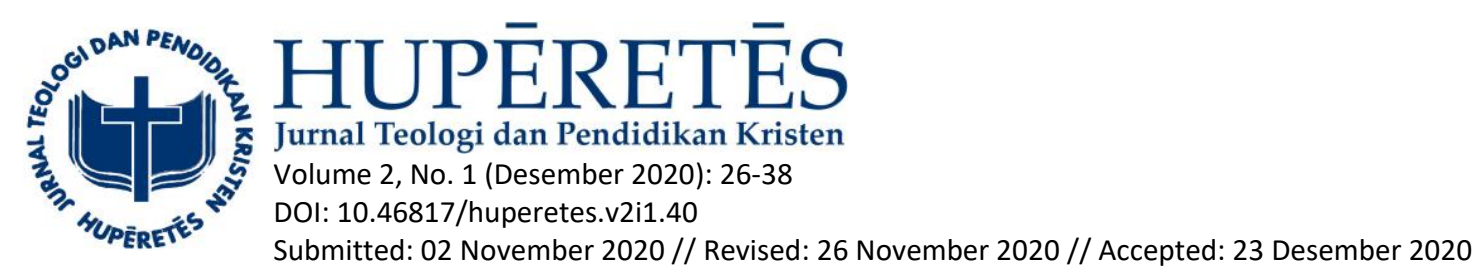

\title{
Studi Eksposisi tentang Penegasan Kembali Perjanjian Allah dengan Abraham dalam Kejadian 15:1-21
}

\author{
Yoseph \\ Sekolah Tinggi Teologi Kalimantan \\ Korepondensi: yosephsabadak926@gmail.com
}

\begin{abstract}
Abstrak: Alkitab mengungkapkan bahwa setiap orang percaya diberikan hak istimewa yaitu sebagai ahli waris (Yoh. 1:12), termasuk sebagai pewaris dari janji-janji Allah (Rm.8:17; Gal. 4:7; Ef. 3:6). Meskipun demikian orang percaya masih dapat mengalami kesulitan hidup. Alkitab menunjukkan bahwa orang percaya juga dapat mengalami fluktuasi dalam hal iman sebagai akibat dari keadaan yang terjadi disekitarnya, seperti contohnya Abraham. Oleh karena itu, pembahasan tentang pengalaman Abraham dalam Kejadian 15:1-21 dalam menanti janji Allah menjadi topik yang menarik dan memberi kontribusi bagi orang percaya masa kini dalam mempercayai Allah dan pemeliharaan-Nya di tengah pergumulan hidup. Ada pun lingkup pembahasan artikel ini adalah seputar studi eksposisi mengenai penegasan kembali perjanjian Allah dengan Abraham tentang ahli waris dan tanah perjanjian. Penelitian ini menggunakan metode deskriptif - analitis, yaitu mendeskripsikan atau memberikan gambaran terhadap objek penelitian. Adapun objek penelitian itu berupa data yang diperoleh melalui studi eksposisi terhadap teks yang menjadi pokok pembahasan. Berdasarkan penelitian ditemukan bahwa tokoh seperti Abraham, termasuk orang percaya, dapat mengalami keragu-raguan terhadap janji Allah. Namun di sisi lain, Allah tetap setia dalam memenuhi perjanjian-Nya kepada Abraham dengan memberikan penegasan kembali janji-Nya yang diikat dalam sebuah seremonial perjanjian (Covenant).
\end{abstract}

Kata kunci: eksposisi, perjanjian, Abraham, Kejadian

Abstract: The Bible reveals that every believer is given the privilege of being an heir (John 1:12), including as an heir of God's promises (Rom. 8:17; Gal. 4:7; Eph. 3:6). Even so, believers can still experience difficulties in life. The Bible shows that believers can also experience fluctuations in faith as a result of circumstances that occur around them, such as Abraham's example. Therefore, the discussion of Abraham's experience in Genesis 15:1-21 in waiting for God's promises becomes an interesting topic and contributes to believers today in trusting God and His care during life's struggles. There is also scope for this article to focus on exposition studies regarding the reaffirmation of God's covenant with Abraham regarding heirs and the promised land. This research uses the descriptive-analytical method, which describes or provides an overview of the object of research. The object of research is in the form of data obtained through an exposition study of the text which is the subject of discussion. Based on research it is found that figures like Abraham, including believers, can experience doubts about God's promises. But on the other hand, God remains faithful in fulfilling His covenant to Abraham by reaffirming His promises bound in a covenant ceremonial (Covenant).

Keywords: exposition, covenant, Abraham, Genesis 


\section{PENDAHULUAN}

Pada tahun 2020 ini, tepatnya sejak awal Maret lalu dunia menghadapi tantangan yang berat, yakni wabah covid 19. Dampaknya tidak hanya terhadap kesehatan tetapi juga mempengaruhi banyak aspek kehidupan seperti ekonomi, pendidikan, lapangan perkerjaan, dan lainnya. Hal ini entu menjadi sebuah pergumulan hidup orang percaya. Di sinilah letak sebuah ujian iman bagi orang percaya untuk tetap berpikir jernih dan benar tentang Allah dan pemeliharaan-Nya. Pengalaman hidup Abraham dalam hubungannya dengan Allah dapat menjadi teladan dalam menghadapi pergumulan hidup. Dari satu sisi, Abraham adalah pribadi yang percaya dan menaati Allah (Kej. 12:4). Tetapi di pihak lain, Abraham dalam fase hidupnya pernah mengalami keragu-raguan bahkan keputusasaan ketika menantikan janji Allah, secara khususa berkenaan dengan janji keturunan dan tanah perjanjian. Oleh karena itu, Allah mempertegas kembali janji-Nya sehingga Abraham kembali percaya (Kej.15:6). Dino menyebutkan bahwa Kejadian 15:1-21 melukiskan sikap Abraham yang baru. ${ }^{1}$ Kisah hidup Abraham ini menyingkapkan sebuah kebenaran kepada setiap orang percaya bahwa tidak ada jaminan orang percaya tidak akan pernah mengalami saat-saat tersulit dalam perjalanan hidup ini. Namun Allah dalam kesetiaan-Nya akan terus-menerus memelihara dan menguatkan setiap orang yang mengadalkan Dia. Studi eksposisi terhadap Kejadian 15:1-21 dibatasi pada penegasan kembali janji Allah kepada Abraham yang kemudian diteguhkan dalam seremonial perjanjian.

Ada beberapa artikel yang membahas Kejadian 15:1-21 dalam bentuk eksposisi teks maupun dari aspek kritik literalnya, namun kurang menekankan dalam aspek perjanjian maupun penerapannya bagi orang percaya. ${ }^{2}$

${ }^{1}$ Albertus Dino, "Perjanjian Allah dengan Abraham (Kej. 15:1-21),” www.quoteamor.com, last modified 2019, diakses Desember 17, 2020, https://www.quoteamor.com /2016/11/perjanjian-allah-dengan-abraham-kej-151.html.

${ }^{2}$ Beberapa artikel yang membahas topik ini, diantaranya: Budi Asali, "Eksposisi Kitab Kejadian (Kejadian 15:1-21)," www.golgothaministry.org, diakses
Sedangkan orientasi pembahasan artikel ini lebih kepada penegasan kembali janji Allah kepada Abraham mengenai benih keturunan dan tanah perjanjian serta kontribusinya bagi orang percaya pada masa kini. Adapun janji-janji itu dikukuhkan dalam sebuah seremonial perjanjian. Tujuan pembahasan artikel ini adalah untuk mengungkapkan sebuah kenyataan sebagai kebenaran bahwa Abraham dalam fase hidupnya pernah mengalami keraguan terhadap janji Allah mengenai benih keturunan dan tanah perjanjian. Kebenaran ini merupakan bukti bahwa setiap orang percaya yang memiliki iman besar sekalipun, dalam rentang waktu tertentu, dapat mengalami fluktuasi iman. Orang percaya memiliki potensi untuk menaruh keragu-raguan terhadap Allah yang diimaninya karena hidup itu adalah sebuah realita. Tujuan lainnya adalah untuk mengungkapkan kebenaran bahwa Allah memberikan firman-Nya untuk menguatkan Abraham tentang janji-Nya dengan memberikan penegasan kembali janji itu melalui sebuah seremonial suatu perjanjian.

\section{METODE}

Pembahasan artikel ini menggunakan metode deskriptif - analisis. Dikatakan deskriptif - analisis karena mendeskripsikan atau memberikan gambaran terhadap objek penelitian. Adapun objek penelitian itu berupa data yang diperoleh melalui studi eksposisi terhadap teks yang menjadi pokok pembahasan. Whitney seperti dikutip oleh Nazir menjelaskan bahwa deskriptif adalah "pencarian fakta dengan interpretasi yang tepat." ${ }^{3}$ Selanjutnya, Usman Rianse menjelaskan bahwa metode deskriptif bertujuan untuk menggambarkan secara tepat sifat-sifat suatu individu, keadaan, gejala atau hal-

Desember 17, 2020, http://www.golgothaministry.org/ kejadian/kejadian-15_1-21.htm; Natanael Apriyanto Tarigan, "Menggali Kejadian 15," Amna Emoneth (Article of Theologi and Christian Education), last modified 2015, diakses Desember 17, 2020, https://natanaelat. blogspot.com/2015/04/menggali-kejadian-15.html.

${ }^{3}$ Mohammad Nazir, Metode Penelitian (Jakarta: 
hal yang khusus dalam masyarakat. ${ }^{4}$ Adapun langkah-langkah eksposisi yang ditempuh adalah dimulai dari menyelidiki teks dengan memperhatikan frasa dan struktur kalimat. Dari hasil penyelidikan teks tersebut dibangunlah pokok-pokok pikiran. Selanjutnya mendeskripsikan setiap pokok pikiran tersebut.

Adapun prosedur yang ditempuh adalah menyelidiki teks dan membuat garis besar berdasarkan strukturnya. Langkah selanjutnya membuat penelitian literatur yang berhubungan dengan pokok pembahasan dengan tujuan untuk mendukung dan mempertajam pembahasan.

\section{PEMBAHASAN}

\section{Latar Belakang Teks}

\section{Studi Kata "Perjanjian" (Covenant)}

Kata "Perjanjian" menjadi kata kunci dalam pembahasan ini. Kata tersebut dalam istilah teologinya disebut Covenant. ${ }^{5}$ Istilah ini lebih dekat dengan maksud dalam pembahasan artikel ini daripada janji (promise). Sekalipun demikian, janji adalah bagian dari sebuah perjanjian. Janji diberikan oleh pihak pemberi tanpa harus mendapat persetujuan dari pihak penerima. Sedangkan perjanjian lebih bersifat kesepakatan antara kedua belah pihak yang mengadakan perjanjian itu. Ini adalah arti dasar dari sebuah perjanjian, khususnya antara seorang dengan orang lain, satu negara ke negara lain, atau seorang penguasa dengan rakyatnya.

Penggunaan istilah perjanjian sangat luas dalam Alkitab. Richards menyatakan bahwa penggunaan konsep perjanjian (berith) tidak dibangun secara eklusif dalam Alkitab. Kebiasaan pada masa awal Alkitab digunakan meliputi antar pribadi atau hubungan sosial. Bahkan perjanjian itu adalah ide Allah yang fundamental untuk menjelaskan atau

${ }^{4}$ Usman Rianse, Metodologi Penelitian Sosial dan Ekonomi: Teori dan Aplikasi (Bandung: CV. Alfabeta, 2008), 26-27.

${ }^{5}$ R. Sudarmo, Kamus Istilah Teologi (Jakarta: BPK Gunung Mulia, 2002), 35. menyatakan hubungan di mana Dia mengadakan perjanjian dengan umat-Nya. ${ }^{6}$

Secara etimologi kata perjanjian dalam Perjanjian Lama berasal dari istilah Ibrani "berith." Kata ini berasal dari kata "barah" yang artinya "memotong." Kata "berith" diduga berasal dari bahasa Asyur "beritu" yang berarti mengikat. ${ }^{7}$ Penggunaannya sangat berhubungan dengan upacara ketika perjanjian itu dibuat, dimana kedua belah pihak akan mengadakan perjanjian sebagai tanda kesepakatan di antara keduanya. Perjanjian itu biasanya diteguhkan dengan upacara seremonial perjanjian. Maknanya adalah sebuah kesepakatan atau persetujuan kerjasama yang dibuat mengenai rencana kegiatan. Selanjutnya, sehubungan dengan perjanjian Allah dengan manusia secara teologis sedikit berbeda. Perbedaannya terletak pada Allah sendiri yang membuat perjanjian-Nya dan dilakukan secara sepihak berdasarkan otoritas-Nya.

Dalam Kejadian 15, Allah merendahkan diri dengan menempatkan diri-Nya secara simbolis di bawah kutukan untuk menegaskan kepada Abraham kepastian janji-janji-Nya. Allah bersumpah, tidak ada apa pun yang diminta dari Abraham (kecuali upacara sunat sebagai tanda ikatan perjanjian, lihat Kej. 17). ${ }^{8}$

Dengan demikian Allah mengikatkan diri-Nya kepada pribadi atau suatu bangsa yang kepadaNya perjanjian itu diberikan. Dengan demikian, dalam Kejadian 15 ini Allah mengikatkan diriNya kepada Abraham melalui seremonial perjanjian (covenant) untuk mempertegas kembali apa yang sudah dijanjikan-Nya di Haran.

\section{Latar Belakang Geografis}

Kepentingan pembahasan ini adalah untuk memberikan penegasan bahwa secara geografis,

${ }^{6}$ Lawrence O. Richards, "Covenant," Expository Dictionary of Bible Words (Grand Rapids: Zondervan Publishing House, 1995), 194.

${ }^{7}$ Yakob Tomatala, Teologi Misi (Jakarta: YT Leadership Foundation, 2003), 91.

${ }^{8}$ W. S. LaSor, D. A. Hubbard, dan F. W. Bush, Pengantar Perjanjian Lama 1: Taurat dan Sejarah (Jakarta: BPK Gunung Mulia, 2001), 168. 
perjanjian Allah dengan Abraham dibuat setelah Abraham berada di tanah yang dijanjikan. Ini berarti dari pihak Abraham yang mendapat janjijanji Allah telah memenuhi panggilan-Nya (Kej. 12:1-3) dengan meninggalkan rumah ayahnya dan daerahnya. Pernyataan ini dapat ditelusuri melalui penceritaan naratif perjalanan Abraham yang dituliskan dalam Kejadian 12-15. Abraham melakukan seperti yang diperintahkan Allah kepadanya (Kej. 12:4-5). Adapun Kejadian 12:6 menjelaskan secara singkat bahwa Abraham telah melintasi daerah hingga sampai di daerah dekat Sikhem, daerah Negeb. Sikhem merupakan daerah yang dijanjikan Tuhan. Wenham menjelaskan "Sikhem itu sendiri adalah merupakan daerah Kanaan di mana penduduknya tinggal di sana. Bahkan Sikhem merupakan pusat terpenting pada milenium ke dua." Kemudian Davis menjelaskan perjalanan tersebut "Abraham menyeberangi sungai Efrat dan menuju barat ke Aleppo, kemudian ke selatan sepanjang sungai Orontes melintasi Libanon dan pengunungan Anti-Libanon."10 Selanjutnya dalam Kejadian 12:8-9 dikatakan bahwa Abraham berpindah lagi dari Sikhem menuju pegunungan di sebelah timur Betel, yaitu antara Betel dan $\mathrm{Ai}$ di sebelah timur. Menurut Samuel, letaknya kira-kira 19,3 km di sebelah utara Yerusalem. Perpindahan Abraham ke Kanaan menjadi pokok perhatian dalam perkembangan sejarah dan geografi pada masa Alkitab. ${ }^{11}$

Berdasarkan penceritaan naratif Kejadian 12 15 serta didukung oleh data di atas, maka dapat dipastikan bahwa Abraham telah melewati batas geografis dari Haran di Mesopotamia ke tanah Kanaan. Jadi secara geografis Abraham menerima Perjanjian (Kej. 15) ketika ia sudah berada di tanah yang dijanjikan Allah, yaitu tanah yang akan diberikan Allah kepada

${ }^{9}$ Gordon J. Wenham, “Genesis 1-15," in Word Biblical Commentary Volume 1, ed. Bruce M. Metzger, David A. Hubbard, dan Glenn W. Barker (Dallas: Word Books, 1987), 279.

${ }^{10}$ John J. Davis, Eksposisi Kitab Kejadian (Malang: Gandum Mas, 2001), 183.

${ }^{11}$ Samuel J. Schultz, The Old Testament Speaks (New York: Harper and Row Publishing, 1943), 26.
Abraham dan keturunannya (Kej. 12:6-9; 13:1218).

\section{Panggilan Abraham sebagai Dasar Perjanjian}

Perintah Tuhan kepada Abraham untuk meninggalkan negerinya, sanak saudaranya, rumah bapanya dan pergi ke negeri yang akan ditunjukkan Tuhan kepadanya (Kej. 12:1-3) merupakan dasar dari perjanjian Allah dengan Abraham. Dikatakan dasar karena perjanjian itu sendiri bertitik tolak pada panggilannya. Dalam istilah lain bahwa perjanjian yang diadakan dalam Kejadian 15 merupakan penegasan dari sebuah perjanjian yang ditandai dengan korban binatang tentang apa yang Tuhan sudah nyatakan kepada Abraham dalam Kejadian 12:13. Seperti yang ditegaskan oleh Dyrness, "Dasar perjanjian ini telah ada dalam Kejadian 12:1-3, ketika Allah memanggil Abraham untuk meninggalkan negerinya, serta berjanji akan menjadikannya suatu bangsa yang besar."12 Sedangkan Marantika mengatakan bahwa perjanjian Abraham yang dicatat dalam Kejadian 15 adalah sebuah pengesahan melalui persembahan binatang. ${ }^{13}$ Janji yang sudah diterima Abraham ketika masih di Haran dipertegas kembali dan disahkan melalui seremonial perjanjian. Tindakan Abraham untuk mengikuti panggilan Allah adalah sematamata tindakan iman. Bahkan Lempp menuliskan bahwa kepergian Abraham dari rumah bapanya (Terah) di Haran adalah merupakan tindakan yang tak lazim karena berlawanan dengan budaya setempat. Hal ini disebabkan karena pada umumnya seorang anak harus memenuhi kewajibannya terhadap orangtua pada masa mereka tua untuk tinggal bersama bapanya, apalagi saudara Abraham telah meninggal. ${ }^{14}$

Panggilan Abraham merupakan babak baru dalam pelaksanaan misi Allah bagi dunia ini. Disinilah Allah menyatakan diri dengan jelas

${ }^{12}$ William Dyrness, Tema-Tema dalam Teologi Perjanjian Lama (Malang: Penerbit Gandum Mas, 2004), 99.

${ }^{13}$ Chris Marantika, Eskatologi (Yogyakarta: Iman Press, 2004), 99.

${ }^{14}$ Walter Lempp, Tafsir Kejadian 5:1 - 12:3 (Jakarta: BPK Gunung Mulia, 1989), 190. 
akan berhubungan dengan bangsa-bangsa melalui Abraham yang kemudian keturunannya akan menjadi bangsa pilihan untuk meneruskan berkat Abraham tersebut. Adapun yang dimaksudkan dengan keturunannya adalah Israel sebagai keturunan Abraham secara daging.

Dalam panggilan Abraham tersebut (Kej. 12:1-3), ada empat berkat yang dijanjikan Allah kepadanya. Janji-janji yang sama secara terus menerus diperteguh kepada generasi bapakbapak leluhur sesudah Abraham seperti kepada Ishak (Kej. 26:2-4), Yakub (Kej. 28:13-14; 35:1112) dan melalui berkat Yakub kepada anak-anak Yusuf (Kej. 48:1-6). ${ }^{15}$ Ada pun keempat berkat tersebut yaitu: Pertama, berkat individual (Kej. 12:2b). Berkat ini mengandung janji tentang harta kekayaan dan kemasyuran yang Allah akan berikan kepada Abraham. Berkat ini bersyarat, yaitu untuk mendapatkannya dituntut kepercayaan dan ketaatan.

Rupanya aspek berkat ini bersyarat, berkat hanya diperoleh karena iman dan ketaatan (respon perseorangan). Yakub misalnya tidak diberkati karena taktik duniawi yang dipakainya dalam mengejar perjanjian itu. Anaknya Yusuf, sebaliknya menjadi teladan penggenapan aspek nubuatan Abraham ini karena karakter ilahinya. Perjanjian ini merupakan hukum umum yang bersyarat dan berlaku bagi setiap manusia. ${ }^{16}$

Kedua, berkat teritorial (Kej. 12:1). Janji territorial adalah hubungan dengan wilayah atau daerah yang akan menjadi milik Abraham dan keturunannya. Tentang status kepemilikan wilayah tersebut akan menjadi milik untuk selama-lamanya. Kejadian 12:1-3 menekankan bahwa tanah tersebut akan menjadi hak milik untuk selama-lamanya. ${ }^{17}$ Ada beberapa ayat yang menolong untuk menunjukkan tanah mana yang dimaksudkan Allah dalam perjanjian-Nya kepada Abraham (Kej. 12:6-9), dimana Allah menampakkan diri kepada Abraham dan berjanji akan memberikan negeri itu kepada keturunannya. Jadi, yang dimaksudkan wilayah

\footnotetext{
${ }^{15}$ LaSor, Hubbard, dan Bush, Pengantar Perjanjian Lama 1: Taurat dan Sejarah, 164-165.

${ }^{16}$ Ibid, 32.

${ }^{17}$ Charles C. Ryrie, Teologi Dasar (Yogyakarta: Andi Offset, 1996), 269.
}

teritorial yang akan diberikan Allah kepada Abraham adalah tanah Kanaan. Tanah Kanaan diberikan Allah kepada Abraham secara sepihak. Abraham pernah tinggal di sebagian tanah itu tetapi ia tidak memilikinya secara utuh. ${ }^{18}$

Ketiga, menjadi bangsa yang besar (Kej. 12:2). Kaiser menjelaskan sehubungan dengan struktur anak kalimat dengan berkat ketiga ini:

\begin{abstract}
Selain itu, arti dari anak kalimat ketiga dan dua anak kalimat terdahulu, untuk pertama kalinya menjadi jelas ketika anak kalimat berikutnya ditambahkan pada ketiga anak kalimat yang terdahulu itu... Kalimat tersebut menyatakan tujuan dan rencana Tuhan untuk membuat Abraham begitu beruntung: "dan engkau akan menjadi berkat” (Kej.12:2). Dalam bahasa Ibrani berbunyi weheyeh berakah. Dengan demikian suatu sasaran pendahuluan telah dicapai dalam hubungan yang diumumkan ini. Abraham akan menjadi bangsa yang besar, diberkati secara pribadi, dan namanya akan masyhur supaya akan menjadi berkat. ${ }^{19}$
\end{abstract}

Analogi yang dipakai untuk menjelaskan besarnya jumlah keturunan Abraham adalah seperti "debu tanah banyaknya" (Kej. 13:16) dan seperti "bintang di langit" (Kej. 15:5). "Namun bangsa besar itu secara spesifik dijanjikan kepada Daud dan keturunannya. Selanjutnya perjanjian ini diperluas dalam perjanjian Daud." 20 Janji-Nya untuk menjadikan Abraham sebagai bangsa yang besar dapat dilihat dari cakupan sempit dan luas. Secara sempit menunjuk kepada satu bangsa yaitu bangsa yang berasal dari keturunan Abraham secara daging dan dipertegas lagi dalam Kejadian 15:4. Sedangkan secara luas adalah setiap orang yang dicangkokkan melalui iman kepada Yesus Kristus (Rm. 4:11; Gal. 3:29). Berkat terakhir yang dijanjikan Tuhan adalah "berkat Spiritual." Allah akan menjadikan Abraham sebagai saluran berkat bagi semua kaum di muka bumi. Anak kalimat "olehmu semua kaum di muka bumi akan mendapat berkat (Kej.12:3c) merupakan tujuan dan kemauan Allah, di mana setiap orang menanggapi berkat Abraham tersebut. Dalam anak kalimat ini terjadi betapa pertukaran yang

\footnotetext{
${ }^{18}$ Marantika, Eskatologi, 32-33.

${ }^{19}$ Walter C. Kaiser, Teologi Perjanjian Lama (Malang: Penerbit Gandum Mas, 2000), 120.

${ }^{20}$ Marantika, Eskatologi, 33.
} 
begitu biasa dan begitu pribadi antara satu individu dengan Allahnya sekarang meluas dan begitu cepat." ${ }^{21}$ Artinya bahwa semua berkat yang sebelumnya terfokus kepada Abraham, tetapi kini Allah berfokus kepada menjadikan Abraham saluran berkat bagi bangsa-bangsa. Hal ini sangat terkait dengan janji Allah dalam protoevanglium (Kej. 3:15). Keuniversalan berkat Abraham ini, yaitu Yesus Kristus, dimaksudkan supaya di dalam Dia berkat Abraham sampai kepada bangsa-bangsa lain sehingga oleh iman kita menerima Roh yang telah dijanjikan itu (Gal. 3:14). Berkat ini oleh Paulus ditafsirkan sebagai berkat bagi bangsa-bangsa kafir (nonYahudi) melalui Yesus Kristus.

\section{Penegasan Perjanjian tentang Ahli Waris (Kej. 15:1-6)}

Penceritaan naratif Kejadian 15:1-21 berbicara tentang perjanjian Allah dengan Abraham, di mana Allah menegaskan kembali janji-Nya yang sebelumnya pernah diberikan kepada Abraham ketika Allah memanggil dia di Haran, Ur Kasdim (Kej. 12:1-3). Isi perjanjian yang dipertegas oleh Allah ada dua, yaitu tentang ahli waris yang lahir dari Abraham sendiri dan berkenaan dengan tanah perjanjian.

Masa penantian Abraham tentang ahli waris, yaitu keturunan yang lahir dari Abraham sendiri, merupakan masa yang sangat sulit. Dikatakan sulit karena secara fisiologis, Abraham dan Sara telah mencapai usia yang tidak produktif lagi untuk mendapatkan keturunan. Inilah isu utama pergumulan Abraham, yaitu menantikan penggenapan janji Allah tentang keturunan. Di satu pihak, keinginan untuk memperoleh keturunan merupakan keinginan tertinggi bagi kaum pengembara, termasuk Abraham, karena dengan demikian mereka dapat mempertahankan hidup. ${ }^{22}$ Di pihak lain, Abraham dituntut untuk meyakini terus janji Allah sekalipun secara fisik semakin merosot karena penuaan.

\footnotetext{
${ }^{21}$ Lempp, Tafsir Kejadian 5:1 - 12:3, 199.

${ }^{22}$ Ibid, 110.
}

\section{Allah Berbicara kepada Abraham dalam Penglihatan}

Kejadian 15 dimulai dengan penyataan firman Tuhan kepada Abraham dalam suatu penglihatan (ay.1). Firman Tuhan yang datang kepada Abraham merupakan penyataan yang agung mengenai kemauan dan rencana Allah tentang Abraham. Lampp mengatakan bahwa penyataan kali ini lebih luhur dan lebih megah daripada yang datang kepada Abraham sebelumnya di Haran, Urkasdim (Kej. 12:1). ${ }^{23}$ Pengalaman saat berlangsungnya proses penglihatan itu seolah-olah seseorang melakukan interaksi dengan menggunakan pancaindra, tetapi pada hakikatnya tidak. Di mana ia sedang berada dalam suasana yang berbeda, namun masih sesadar-sadarnya (tidak bermimpi). "Kesadarannya tidak disingkirkan, melainkan dipertajam dan dipertinggi lebih dari biasa." 24 Namun yang menonjol dalam penglihatan itu adalah bukan apa yang dilihat, melainkan firman yang disampaikan.

Allah mendorong Abraham supaya jangan takut (Kej. 15:1b). Ada beberapa kemungkinan yang menyebabkan Abraham mengalami ketakutan. Namun Leupold mengatakan "untuk menemukan mengapa Abraham takut merupakan kesulitan besar." ${ }^{25}$ Cara paling dekat dan sangat mungkin untuk memahami ketakutan Abraham adalah dari responnya terhadap firman yang disampaikan Allah kepadanya, yaitu Abraham takut meninggal tanpa ahli waris. Davis mengatakan "Tanggapan Abraham menunjukkan keprihatinan yang mendalam karena ia tidak mempunyai anak sebagai ahli waris." ${ }^{26}$ Karena itu, Allah merasa bahwa Abraham perlu mendengar secara baru janji dan jaminan Allah yaitu "janganlah takut." Allah sendiri menempatkan diri-Nya sebagai pelindung atau perisai Abraham (Kej. 15:1) dari berbagai ketakutan, baik terhadap keraguan penggenapan ahli waris, maupun dari ketakutan terhadap musuh-musuh yang mendiami tanah

\footnotetext{
${ }^{23} \mathrm{Ibid}, 114$.

${ }^{24} \mathrm{Ibid}$.

${ }^{25} \mathrm{H}$. C. Leupold, Exposition of Genesis (Grand Rapids, MI: Baker Book House, 1982), 472.

${ }^{26}$ Davis, Eksposisi Kitab Kejadian, 196.
} 
yang dijanjikan kepadanya. Ungkapan yang digunakan adalah "Akulah perisaimu" (anoki magen lak). Hal ini menjelaskan bahwa Allah sendiri menyatakan diri-Nya sebagai pribadi yang melindunginya dan akan menggenapi semua janji yang sudah diterimanya dari Allah. ${ }^{27}$ Demikianlah Allah menyatakan diri-Nya kepada Abraham sebagai pelindung dan penjaga Abraham dalam menjalani panggilan Tuhan serta menantikan janji Tuhan tentang ahli waris. Ungkapan selanjutnya adalah "upahmu sangat besar" (gekarka harbeh meod). Frase ini memberikan indikasi adanya janji Allah tentang apa yang sudah diperoleh Abraham (Kej. 13:2) akan bertambah-tambah besar. Kyle mengatakan "Abraham perlu melihat kepastian tentang upah yang dapat menghasilkan sukacita yang penuh." 28 Berkat keturunanlah yang memberikan sukacita bagi Abraham. Pemberian upah dilakukan kepada orang yang telah memenuhi syarat tertentu untuk mendapatkannya. Keterkaitannya dengan janji Allah yang memberitahukan tentang upah Abraham akan menjadi besar karena Abraham dianggap memenuhi standar tertentu. Dalam hal ini, kelayakan Abraham semata-mata didasarkan pada ketaatannya untuk memenuhi panggilan Tuhan.

\section{Jawaban Abraham kepada Allah}

Kejadian 15:2-3 merupakan respon pertama Abraham dalam dialog antara Allah dan Abraham setelah Allah memberikan penghiburan serta janji-Nya. Menurut Hamilton, "bahwa ini adalah pertama kalinya terjadi dialog antara Abraham dan Allah, sebelumnya hanya bersifat monolog (Kej. 12:1-7; 13:14), dimana Abram hanya mendengar dan melakukan saja." 29 Menarik disimak bahwa Abraham menyapa Allah dengan ungkapan (adonay yahweh) "Tuhan Allah.” Penyebutan semacam ini adalah

${ }^{27}$ F. L. Baker, Sejarah Kerajaan Allah Jilid 2: PL (Jakarta: BPK Gunung Mulia, 1978), 106.

${ }^{28}$ Charles F. Pfeiffer dan Everett F. Harrison, ed., Tafsiran Alkitab Wycliffe Volume 1: Kejadian - Ester (Malang: Penerbit Gandum Mas, 2007), 74.

${ }^{29}$ Victor P. Hamilton, The Book of Genesis Chapter 1. 17 (Grand Rapids, MI: William B. Eerdmans Publishing Company, 1987), 419. pemunculan pertama kalinya dalam Alkitab. Hal ini menunjukkan betapa dalam teologi Abraham sehubungan dengan pemahamannya tentang Allah. Artinya, Abraham memandang Allah sebagai Pemberi janji sekaligus penjamin atas janji-Nya termasuk jaminan keselamatan. Menurut Davis, penggunan ungkapan adonay yahweh oleh Abraham menunjukkan teologinya tentang Allah sebagai Tuhan (adonay) karena Ia adalah tuannya dan sebagai Allah (Yahweh) karena Ia telah memberinya janji-janji perjanjian. ${ }^{30}$ Jadi, keraguan Abraham (Kej. 15:23) bukan pada hal meragukan kesanggupan Allah untuk memenuhi janji-Nya, melainkan lebih kepada apakah Allah berkenan memberikan kepada Abraham anak sebagai ahli waris. Inilah pergumulan terberat Abraham sehingga memunculkan pertanyaan seputar ahli waris. Menurut Lampp, pergumulan itu mengandung kesangsian dan keragu-raguan hati Abraham yang hendak menuruti Allah dan tidak dapat lagi bertekun bahwa Allah akan menggenapi janji-Nya. ${ }^{31}$

Pertanyaan dan pernyataan Abraham kepada Allah adalah ungkapan hatinya yang sedang dalam pergumulan batin. Anak kalimat "apakah yang akan Engkau berikan kepadaku?" Abraham telah memperoleh banyak harta dan sejumlah budak yang Allah berikan kepadanya. Karena itu, pertanyaan ini adalah sebuah ungkapan tentang keinginan tertinggi dan harapan terbesar Abraham tentang seorang anak sehingga keturunan dan masa depannya terjamin. Hal ini dapat dipahami karena ketiga anak kalimat selanjutnya "karena aku akan meninggal dengan tidak mempunyai anak, dst." Inilah sebuah keluh kesah Abraham dimana pikirannya mulai dipengaruhi nilai-nilai manusiawi yang kemudian melihat dirinya dan Sara yang sudah tua dan melampaui batas-batas kemampuan untuk beranak. ${ }^{32} \mathrm{Hal}$ ini diperkuat karena pada ayat 4 Allah membantah Abraham yang menduga bahwa Eliezerlah yang akan menjadi ahli warisnya.

\footnotetext{
${ }^{30}$ Davis, Eksposisi Kitab Kejadian, 197.

${ }^{31}$ Lempp, Tafsir Kejadian 5:1 - 12:3, 116.

${ }^{32}$ Davis, Eksposisi Kitab Kejadian, 197.
} 
Allah Berbicara kepada Abraham dengan Janji

Bagian ini merupakan tanggapan Allah terhadap pernyataan Abraham. Kalimat "Tetapi datanglah firman TUHAN kepadanya, ...” (Kej. 15:4). Setiap kalimat yang diawali dengan "firman Tuhan" atau "Tuhan berfirman" selalu menandakan peristiwa itu sangat penting. Menurut Leupold "sebab firman Allah selalu merupakan peristiwa yang sangat penting untuk diperhatikan." 33 Berfirmannya Allah kepada Abraham memberikan indikasi bahwa Allah tidak membenarkan atau meluruskan jalan pikiran Abraham untuk memperoleh keturunan dari garis budak, meskipun hal itu dapat dibenarkan menurut hukum di Mesopotamia dengan cara mengadopsi.

Dengan menyampaikan firman-Nya kepada Abraham (Kej. 15:5-6), maka segala keputusasaan dan kecurigaan atau kesangsian Abraham terhadap janji Allah di masa lalu dipertentangkan dengan firman yang adalah janji resmi Allah. "Firman itulah yang hendak menegaskan dan meneguhkan hati Abraham yang telah bimbang dan pusing kepala. Firman Allah melawan dan menantang ketakutan dan kegelisahan hati manusia dan memberikan kepastian dan ketetapan hati." ${ }^{34}$ Dengan demikian, hati Abraham yang mulai dipenuhi keraguan kini diperhadapkan kembali dengan janji dari Sang pemberi firman.

Dilihat dari dialog dalam teks ini, naratifnya menjelaskan bahwa Allah memfokuskan firmanNya kepada kebutuhan dasar dan harapan terbesar Abraham kepada-Nya, yaitu soal keturunan. Pertama, Allah menolak pernyataan Abraham yang mengatakan "Eliezer akan menjadi ahli warisnya. Penyangkalan Allah terhadap Eliezer sebagai ahli waris menunjukkan bahwa rencana Allah sangat kontradiktif dengan pikiran Abraham yang dipengaruhi oleh nilainilai manusiawi. Sedangkan Allah tidak dipengaruhi oleh keadaan lahiriah Abraham dan Sara yang semakin merosot untuk melaksanakan rencana-Nya dalam menggenapi janji-Nya kepada Abraham. Kedua, frase "melainkan anak

\footnotetext{
${ }^{33}$ Leupold, Exposition of Genesis, 475.

${ }^{34}$ Lempp, Tafsir Kejadian 5:1 - 12:3, 118.
}

kandungmu, dialah yang akan menjadi ahli warismu," (Kej. 15:4b). Ayat ini berarti bahwa yang akan menjadi ahli waris Abraham adalah anak yang keluar dari tubuhnya sendiri, bukan anak yang diadopsi. Leupord mengatakan “... tetapi keturunan yang langsung dari dirimu sendiri. Pengertian me'mekha "dari perut," adalah sebuah ungkapan mengenai kelangsungan organ (daging)." ${ }^{35}$ Ringkasnya, anak yang dimaksud oleh Allahm untuk menjadi ahli waris seluruh berkat Abraham adalah bukan anak yang akan diadopsi atau anak Abraham dari jalur lain (Kej. 21:13), melainkan anak kandung Abraham yang lahir dari Sara. Ketiga, Allah menjadikan sejumlah bintang di langit sebagai analogi keturunan Abraham. Ada beberapa cara yang digunakan oleh Allah dalam Alkitab sebagai analogi untuk membandingkan jumlah keturunan Patriach (Kej. 13:16; 22:17; 26;4; Ibr. 11:12). Dalam Kejadian 15:5, Allah menggunakan bintang di langit sebagai perbandingan keturunan Abraham nantinya. Wenham mengatakan bahwa kata kerja "lihatlah" memberikan kesan tindakan melihat kejauh, sedangkan kata benda "bintang-bintang" menunjuk kepada suatu perbandingan yang menyatakan ketidaksanggupan untuk menghitung keturunan Abraham. ${ }^{36}$ Jadi, hal yang menjadi titik realistisnya ada pada "ketidaksanggupan menghitung." Peristiwa ini terjadi di luar perkembahan Abraham. "Ketika Abraham berbaring di kemahnya, lalu Allah membawanya keluar di bawah lengkungan langit yang ditaburi berlaksa-laksa bintang yang tak terhitung jumlahnya." ${ }^{37}$ Tindakan Allah ini adalah untuk meyakinkan Abraham yang sedang dalam keragu-raguan dalam menanti janji-Nya.

\section{Respon Abraham terhadap Janji Allah}

Abraham merespon janji Allah itu dengan iman (Kej. 15:6b) sekalipun mungkin masih banyak pertanyaan dalam hati tentang bagaimana semua itu akan dipenuhi. Tetapi disinilah titik pentingnya iman untuk meyakini

\footnotetext{
${ }^{35}$ Leupold, Exposition of Genesis, 475.

${ }^{36}$ Wenham, "Genesis 1-15," 329.

${ }^{37}$ Lempp, Tafsir Kejadian 5:1 - 12:3, 119.
} 
sesuatu sebagai kebenaran, walau hal itu tidak dapat ditampung oleh akal manusia yang terbatas. Ungkapan di atas mengandung arti bahwa Abraham memantapkan diri untuk tetap terus-menerus percaya kepada Allah. ${ }^{38}$ Jadi, tindakan Abraham untuk percaya kepada firman Allah adalah sebuah tindakan yang bertentangan dengan kesangsian dan kebimbangan hatinya. Abraham tidak menolak janji itu sebagai janji yang kosong, kesia-siaan belaka, melainkan menerima janji itu dengan baik sebagai kenyataan yang belum tampak atau masih tersembunyi. Iman Abraham adalah respon terhadap janji Allah dan menerima janji itu sebagai kebenaran. Iman itu tidak bertumpu pada apa yang dilihat melainkan kepada suatu perbuatan Allah yang belum tampak sekarang, namun pasti akan tergenapi.

\section{Allah Memperhitungkan Iman Abraham sebagai Kebenaran}

Frase "maka TUHAN memperhitungkan hal itu kepadanya sebagai kebenaran” (Kej. 15:6b) merupakan buah iman Abraham yang diperhitungkan Allah. Lempp mengusulkan kata hasab lebih baik diterjemahkan "menaksir," "menilai," atau "menghargai." ${ }^{39}$ Yang diperhitungkan Allah bukan korban atau hasil keringat Abraham, melainkan "kepercayaan" dimana Abraham membuka hatinya untuk menerima janji itu sekalipun bertentangan dengan keadaan yang sedang ia alami. Hal ini menunjukkan kepatuhan batin, kesadaran, dan kerendahan hatinya di hadapan Allah. Sailhamer berkata bahwa "covenant" tidak dapat membuat Abraham benar, melainkan imannya diperhitungkan benar terlebih dahulu dan setelah itu baru Abraham dapat masuk ke dalam perjanjian dengan Allah. Sailhamer menyatakan syntax pada ayat 6 memberikan kesan dapat dibaca sebagai latar belakang informasi kepada pandangan pembentangan (Kej. 15:7) Allah

${ }^{38}$ William L. Holladay, A Concise Hebrew and Aramaic Lexicon of the Old Testament Based upon the Lexical Work of Ludwig Koehler and Walter Baumgartner (Grand Rapids: William B. Eerdmans Publishing Company, 1988), 20.

${ }^{39}$ Lempp, Tafsir Kejadian 5:1 - 12:3, 122. tentang masuk ke dalam "covenant" dengan Abraham menjadi dasar tansaksi masa depan Allah dengan Abraham dan keturunannya (Kej. 15:7-21). ${ }^{40}$ Jadi maksud dari iman Abraham diperhitungkan sebagai kebenaran adalah bukan Abraham menjadi benar karena jasa imannya, melainkan Allah menganggap benar sikap Abraham yang percaya terhadap janji Allah.

\section{Penegasan Allah tentang Tanah Perjanjian (Kej. 15:7-21)}

Setelah selesai persoalan tentang ahli waris, kini berkenaan dengan firman TUHAN kepada Abraham tentang negeri yang akan menjadi milik pusaka Abraham dan keturunannya (Kej. 12:2). Pada ayat 7-21 ini, dari pihak Abraham lebih banyak melakukan seperti yang Tuhan perintahkan ketimbang menyampaikan keluhannya. Hal ini dapat dimengerti karena Abraham sudah menerima janji ahli waris yang menjadi pergumulan terbesarnya.

\section{Allah Menyatakan Diri kepada Abraham}

Kata "Akulah TUHAN" adalah tindakan Allah yang memperkenalkan diri kepada Abraham. Ini merupakan pertama kalinya Allah memperkenalkan nama-Nya. Sebelumnya Allah berbicara kepada Abraham melalui firman-Nya. Bakker menuliskan bahwa peristiwa ini terjadi pada keesokan harinya dengan alasan ayat 5 Abraham dibawa keluar pada malam hari dan ayat 12, 17 menunjukkan waktu sore hari di mana matahari terbenam. ${ }^{41}$ Adapun tujuan Allah menyatakan nama-Nya bukan supaya dikenal oleh Abraham, melainkan memiliki tujuan yang agung dan mulia bagi Abraham ke depan. Pembukaan rahasia nama Allah merupakan suatu proklamasi yang hendak menuntut dan menyita kehidupan Abraham, sekaligus Allah menaruh perhatian, peduli, menghiraukan nasib Abraham. ${ }^{42}$ Dengan demikian, tindakan memperkenalkan nama-Nya

${ }^{40} J o h n$ H. Sailhamer, "Genesis," in The Expositor's Bible Commentary, ed. Frank E. Gaebelein (Grand Rapids, MI: Zondervan Publishing House, 1990), 129.

${ }^{41}$ Baker, Sejarah Kerajaan Allah Jilid 2: PL, 107.

${ }^{42}$ Lempp, Tafsir Kejadian 5:1 - 12:3, 127. 
menyatakan bahwa Allah memiliki rencana yang besar bagi Abraham. Karena itu, "Akulah TUHAN" harus dipandang sebagai ungkapan bahasa sumpah dimana menegaskan bahwa Allah akan melakukan apa yang Ia janjikan.

\section{Abraham Meminta Tanda dari Allah}

Pengertian "tanda" pada pembahasan ini tidak seperti yang dimaksudkan oleh penggunaannya dalam Alkitab, melainkan istilah ini hanya kata yang merujuk kepada maksud dari pertanyaan Abraham kepada Allah. Pertanyaan dalam Kejadian 15:8 adalah sebuah reaksi Abraham atas janji Allah yang akan memberikan kepadanya negeri yang akan menjadi warisannya. Pertanyaan ini bukanlah sebagai indikasi bahwa iman Abraham menjadi lemah tetapi menjadi suatu kebiasaan yang lazim. Contohnya adalah Gideon (Hak. 6:17;36-40) dan Hizkia (2 Raj. 20:8). Davis melihat bahwa pertanyaan ini bukanlah gejala ketidakpercayaan atau keraguan, melainkan mengungkapkan keingintahuan yang sungguh-sungguh untuk melihat Allah menggenapi janji-janji perjanjian-Nya. ${ }^{43}$ Jadi, pertanyaan ini harus dipandang sebagai tujuan untuk mempertajam atau memperjelas janji Allah untuk digenapi.

\section{Pemotongan Binatang sebagai Bukti Perjanjian}

Jawaban Allah atas pertanyaan Abraham adalah dengan cara Allah mengarahkan Abraham pada peneguhan perjanjian melalui pemotongan binatang sebagai bukti perjanjian antara Allah dan Abraham. Allah menyuruh Abraham mengambil hewan korban yang akan dipakai dalam ritual perjanjian antara Allah dan Abraham (Kej. 15:8-9). Kalimat "ambillah bagiKu” menunjukkan bahwa Allah tidak menjelaskan atau memperdebatkan pertanyaan Abraham, melainkan menuntut kepatuhannya. Wenham berkata bahwa di dalam tanggapan terhadap pertanyaan Abraham, Allah memberikan sebuah perintah yang sering dipakai sebagai perintah dalam pendahuluan untuk

\footnotetext{
${ }^{43}$ Davis, Eksposisi Kitab Kejadian, 199.
}

pengorbanan (Im. 9:2,3). ${ }^{44}$ Semua binatang yang disebutkan dalam ayat 9 adalah spesies binatang yang dikategorikan sebagai binatang yang kudus menurut tata cara ibadat Israel dikemudian harinya (Ul. 14:4,4; Im. 1:10; 3:12; 11:3). Kalimat "Diambillah semuanya itu bagi TUHAN" menyatakan tindakan ketaatan Abraham atas perintah Allah itu. Tindakan yang penting dalam ritual sebuah perjanjian terhadap hewan tersebut adalah memotong. Abraham memotong binatang itu menjadi dua bagian yang sama dan meletakkan kedua bagian itu secara berhadap-hadapan, dihubungkan dengan aliran darah, dan kedua belah pihak yang mengadakan perjanjian tersebut akan melewatinya.

Ada prolog yang dijelaskan sebelum seremonial perjanjian itu diadakan. Ada pun yang dimaksudkan adalah peristiwa yang terjadi di antara pengadaan korban persembahan (Kej. 15:9-10) dengan pelaksanaan perjanjian antara Allah dan Abraham (Kej. 15:17-21). Peristiwa pertama, Allah membuat Abraham tertidur. Kata Ibrani "wetardemah" artinya "tidur nyenyak." Kata yang sama dipakai dalam Kejadian 2:21 "Tuhan membuat manusia itu tidur nyenyak...." Jadi, Abraham tidur nyenyak bukan semata-mata karena faktor kelelahan, melainkan disebabkan oleh Allah. Peristiwa kedua, gelap gulita yang terjadi meliputi Abraham di waktu senja. Fenomena alam semacam ini tidak lazim kecuali Allah yang membuat gelap gulita itu meliputi Abraham. Clark menghubungan gelap gulita itu dengan berita yang akan disampaikan pada ayat 13-14 tentang keadaan tidak mengenakkan yang akan dialami oleh keturunan Abraham, yaitu penderitaan dan kesusahan yang akan dialami oleh anak cucunya selama empat ratus tahun. ${ }^{45}$ Hal yang sama juga dikatakan oleh Ryire bahwa kegelapan yang mengerikan itu dirancang untuk menegaskan kekerasan yang diprediksikan kepada keturunan Abraham di Mesir. ${ }^{46}$ Kemudian Allah memberitahukan kepada Abraham, bahwa Ia akan menghukum bangsa

\footnotetext{
${ }^{44}$ Wenham, "Genesis 1-15," 331.

${ }^{45}$ Adam Clark, Adam Clark's Commentary on The Bible (Grand Rapids, MI: Baker Book House, 1982), 38.

${ }^{46}$ Charles C. Ryrie, The Old Testament Annotated Ryrie Study Bible Expanded Edition (Chicago: Moody Press, 1994), 26.
} 
yang memperbudak mereka. Selanjutnya, suasana dalam menyampaikan firman-Nya (Kej. 15:12-16) sangat berbeda dari sebelumnya, sekaligus sebagai babak persiapan untuk memasuki pelaksanaan perjanjian secara legalitas.

\section{Seremonial Perjanjian antara Allah dan Abraham Diadakan}

Kejadian 15:17-21, khususnya ayat 17-18 adalah klimaks dari peristiwa yang dituliskan dalam Kejadian 15. Dikatakan klimaks karena pada ayat ini perjanjian Abraham diadakan. Dengan kata lain, perjanjian itu disahkan atau dikukuhkan dalam seremonial suatu perjanjian. Peristiwa ini terjadi "ketika matahari terbenam dan hari mulai gelap." Waktu ini menunjuk kepada hari yang sama yang disebutkan pada ayat 12. Kehadiran Allah dalam perjanjian dinyatakan melalui tanda "perapian yang berasap dan suluh yang berapi." Hamilton menghubungkan dengan perisitwa seperti Allah hadir dalam api di gunung Sinai (Kel. 19:18). ${ }^{47}$ Kemudian kedua belah pihak yang mengadakan perjanjian melewati potongan daging itu sebagai simbol bahwa perjanjian itu sudah dipotong atau sudah dibuat. Tetapi dalam peristiwa ini agak berbeda karena hanya perapian yang berasap dan suluh yang berapi melewati potongan daging tersebut. Abraham tidak dilaporkan ikut melewati diantara potongan daging itu. Hal ini menunjukkan bahwa Allah sendiri yang berinisiatif mengikatkan diri-Nya kepada Abraham dalam sebuah perjanjian.

Peristiwa perjanjian itu dibuat (Kej. 15:18) dan diikuti dengan firman Tuhan tentang janjiNya untuk memberikan negeri yang akan menjadi ahli waris Abraham dan keturunannya dengan batasan teritorial tanah perjanjian yang sangat jelas (Kej. 15:18b-21). Batasan daerah yang dimaksudkan harus dipahami secara literal, yaitu mulai dari sungai Mesir sampai sungai Efrat.

\section{Kontribusinya bagi Orang Percaya pada Masa Kini}

Adapun kontribusi dari pembahasan di atas bagi orang percaya pada masa kini dapat dibagi dua, yaitu secara teologis dan praktis. Secara teologis karena memiliki keterkaitan langsung dengan tema-tema teologis, sedangkan secara praktis lebih kepada kehidupan praktis seharihari. Alasan alkitabiahnya bahwa setiap orang percaya di segala zaman, oleh Kristus, adalah juga keturunan Abraham secara rohani yang berhak menerima janji Allah (Gal. 3:29).

\section{Kontribusi Teologis}

Kotribusi teologis ini lebih menyoroti dari pihak Allah, yaitu yang berkenaan dengan sifat dan karya-Nya dalam kaitannya dengan orang percaya. Fokus pembahasannya kepada sifat Allah yang bergiat untuk menguatkan iman Abraham di saat-saat sulit dan juga kepada orang percaya di segala zaman. Pertama, Allah bekerja untuk menguatkan iman Abraham. Penceritaan naratif Kejadian 15 sangat menonjolkan tindakan Allah yang aktif untuk mengkokohkan iman Abraham. Hal ini juga berlaku bagi setiap orang percaya yang hidup dari iman Abraham (Rm. 4:16; Luk.22:32). Kedua, pembenaran oleh iman. Pertama kali dijumpai penggunaan istilah ini dalam Kejadian 15:5. Tindakan Allah ini sebagai upah atas keyakinan Abraham terhadap janji-Nya, sekalipun hal itu berlawanan dengan hukum manusiawinya yang secara fisiologis tidak memungkinkan tetapi ia tetap percaya. Pembenaran Allah oleh iman akan membuat orang percaya mengalami damai sejahtera meskipun pada situasi yang sulit sekalipun (Rm. 5:1). Ketiga, orang percaya sebagai keturunan Abraham secara rohani. Sejak awal kisah hidup Abraham, Allah telah menjadikan dia sebagai saluran berkat bagi bangsa-bangsa (Kej. 12:3). Paulus berkata bahwa setiap orang yang menjadi milik Kristus adalah juga keturunan Abraham dan berhak menerima janji Allah (Gal.3:29). 


\section{Kontribusi Praktis}

Ada empat pokok pikiran yang menjadi kontribusi praktis bagi orang percaya. Pertama, dinamika kehidupan orang percaya. Tidak dapat dipungkiri sebuah kenyataan hidup yang mau tidak mau harus dihadapi, yaitu pengalaman jatuh bangunnya orang percaya dalam menaanti Tuhan. Setiap orang, termasuk orang percaya, memiliki potensi untuk mengalaminya. Karena itu, sebagai pribadi yang lemah orang percaya harus bergantung kepada Allah (Rm. 8:26-27; 2Kor. 12:9). Kedua, hidup dalam iman yang dinamis. Kunci untuk menjadi pemenang dalam menghadapi dan menjalani kehidupan adalah signifikansinya hidup dengan iman yang dinamis. Artinya, iman yang hidup, bertumbuh, dan berakar kuat adalah kekuatan untuk menaklukkan musuh iman itu sendiri, baik yang datang dari luar maupun dari dalam diri (1 Ptr. 1:5-6). Ketiga, signifikansi hidup dalam kebenaran. Seperti Abraham menghidupi imannya kepada Allah dalam kesetiaan, demikian juga setiap orang percaya. Setiap umat Tuhan dituntut untuk senantiasa hidup berpadanan dengan Allah (Ef. 4:1; Flp.1:27). Kebenaran Allah adalah standar tertinggi hidup orang percaya. Keempat, berorientasi pada pengharapan. Salah satu upaya untuk bertahan dan tetap eksis dalam memelihara hubungan yang indah dengan Allah adalah hidup yang senantiasa berorientasi pada pengharapan. Abraham sekalipun belum memiliki semua yang dijanjikan tetapi tetap percaya kepada perjanjian Allah (Ibr. 11:17-19).

\section{KESIMPULAN}

Penegasan kembali perjanjian Allah dengan Abraham merupakan topik utama dalam pembahasan artikel ini, khususnya dalam Kejadian 15:1-21. Perjanjian Abraham adalah Master Plan ilahi dalam karya penyelamatan dunia. Janji-janji yang diberikan Tuhan kepada Abraham (Kej. 12:1-3) adalah upah ketaatan Abraham sekaligus dasar bagi perjanjian antara Allah dan Abraham dalam Kejadian 15. Ketika Abraham dipanggil dari Haran, ada empat janji yang diberikan kepada Abraham yaitu berkat individual (pribadi), berkat territorial (wilayah), berkat nasional dan berkat spiritual.

Penceritaan naratif dalam Kejadian 15:1-21 menggambarkan terjadinya sebuah dialog antara Allah dan Abraham. Allah mempertegas kembali janji-Nya tentang ahli waris dan negeri yang akan Allah berikan kepada Abraham. Dipihak lain, Abraham meresponi janji-janji itu yang dimulai dari menyampaikan keluhan atas keraguraguannya hingga pada respon tertingginya. Adapun klimaks dari respon Abraham adalah ia percaya kepada janji-janji itu dan Allah memperhitungkan kepadanya sebagai kebenaran. Akhirnya, semua janji-janji Allah kepada Abraham diteguhkan atau disahkan dalam sebuah ritual perjanjian, dimana Allah merendahkan diri dan mengikatkan diri-Nya kepada Abraham melalui perjanjian tersebut. Allah pasti memenuhi semua yang dijanjikanNya.

Perjanjian Abraham ini tidak hanya berlaku bagi keturunan Abraham secara daging, melainkan ada berkat spiritual yang dapat berlaku bagi semua orang yang hidup dengan iman Abraham. Hal ini dapat dimungkinkan oleh Yesus Kristus yang telah membuat berkat Abraham sampai kepada bangsa-bangsa (Gal. 3:14,29). Kontribusi teologis dari pembahasan ini yaitu Allah bekerja secara aktif terus-menerus untuk menguatkan iman. Kita dibenarkan oleh karena iman. Kontribusi praktisnya, karena perjalanan hidup adalah sebuah dinamika maka orang percaya harus memiliki pemikiran betapa pentingnya hidup dalam iman yang dinamis, tentang signifikansi hidup dalam kebenaran, serta berorientasi pada pengharapan.

\section{KEPUSTAKAAN}

Asali, Budi. "Eksposisi Kitab Kejadian (Kejadian 15:1-21)." www.golgothaministry.org. Diakses Desember 17, 2020. http://www.golgotha ministry.org/kejadian/kejadian-15_121.htm.

Baker, F. L. Sejarah Kerajaan Allah Jilid 2: PL. Jakarta: BPK Gunung Mulia, 1978.

Clark, Adam. Adam Clark's Commentary on The Bible. Grand Rapids, MI: Baker Book 
House, 1982.

Davis, John J. Eksposisi Kitab Kejadian. Malang: Gandum Mas, 2001.

Dino, Albertus. "Perjanjian Allah dengan Abraham (Kej. 15:1-21)." www.quoteamor .com. Last modified 2019. Diakses Desember 17, 2020. https://www. quoteamor.com/2016/11/perjanjian-allahdengan-abraham-kej-151.html.

Dyrness, William. Tema-Tema dalam Teologi Perjanjian Lama. Malang: Penerbit Gandum Mas, 2004.

Hamilton, Victor P. The Book of Genesis Chapter 1-17. Grand Rapids, MI: William B. Eerdmans Publishing Company, 1987.

Holladay, William L. A Concise Hebrew and Aramaic Lexicon of the Old Testament Based upon the Lexical Work of Ludwig Koehler and Walter Baumgartner. Grand Rapids: William B. Eerdmans Publishing Company, 1988.

Kaiser, Walter C. Teologi Perjanjian Lama. Malang: Penerbit Gandum Mas, 2000.

LaSor, W. S., D. A. Hubbard, dan F. W. Bush. Pengantar Perjanjian Lama 1: Taurat dan Sejarah. Jakarta: BPK Gunung Mulia, 2001.

Lempp, Walter. Tafsir Kejadian 5:1 - 12:3. Jakarta: BPK Gunung Mulia, 1989.

Leupold, H. C. Exposition of Genesis. Grand Rapids, MI: Baker Book House, 1982.

Marantika, Chris. Eskatologi. Yogyakarta: Iman Press, 2004.

Nazir, Mohammad. Metode Penelitian. Jakarta: Gloria Indonesia, 1985.

Pfeiffer, Charles F., dan Everett F. Harrison, ed. Tafsiran Alkitab Wycliffe Volume 1: Kejadian. Ester. Malang: Penerbit Gandum Mas, 2007.

Rianse, Usman. Metodologi Penelitian Sosial dan Ekonomi: Teori dan Aplikasi. Bandung: CV. Alfabeta, 2008.

Richards, Lawrence O. "Covenant." Expository Dictionary of Bible Words. Grand Rapids: Zondervan Publishing House, 1995.

Ryrie, Charles C. Teologi Dasar. Yogyakarta: Andi Offset, 1996.

- The Old Testament Annotated Ryrie Study Bible Expanded Edition. Chicago: Moody Press, 1994.
Sailhamer, John H. "Genesis." In The Expositor's Bible Commentary, diedit oleh Frank E. Gaebelein. Grand Rapids, MI: Zondervan Publishing House, 1990.

Schultz, Samuel J. The Old Testament Speaks. New York: Harper and Row Publishing, 1943.

Sudarmo, R. Kamus Istilah Teologi. Jakarta: BPK Gunung Mulia, 2002.

Tarigan, Natanael Apriyanto. "Menggali Kejadian 15." Amna Emoneth (Article of Theologi and Christian Education). Last modified 2015. Diakses Desember 17, 2020. https://natanaelat.blogspot.com/ 2015/04/menggali-kejadian-15.html.

Tomatala, Yakob. Teologi Misi. Jakarta: YT Leadership Foundation, 2003.

Wenham, Gordon J. “Genesis 1-15." In Word Biblical Commentary Volume 1, diedit oleh Bruce M. Metzger, David A. Hubbard, dan Glenn W. Barker. Dallas: Word Books, 1987. 